\title{
INFORMATION AND COMMUNICATION IN Public Administration in the Context of Management Control Functioning in the Public Finance Sector in Poland
}

\author{
Ambroży Mituś \\ Department of Public Law, Cracow University of Economics, Poland \\ mitusa@uek.krakow.pl
}

MITUŚ Ambroży. Information and Communication in Public Administration in the Context of Management Control Functioning in the Public Finance Sector in Poland. International and Comparative Law Review, 2016, vol. 16, no. 2, pp. 181-196. DOI: 10.1515/iclr-2016-0023.

\begin{abstract}
Summary: The aim of this article is to present the essence and significance of information and communication in public administration in the context of the management control. Broadly understood information in public administration allows both to control the activity of this administration and to make correct decisions and actions in order to perform public tasks effectively. Therefore, the existence of a proper system for sharing and exchanging information is an essential component of the management control, ensuring the execution of the tasks and objectives in a way that is consistent with the law, effective, efficient and timely. The article points to i.a. the types of information and means of communication that may be deemed effective or legally acceptable tools for conveying information and communicating in public information. In this context it should be emphasised that - in particular - sharing public information requires that a relevant form be retained and a proper sharing procedure be followed.
\end{abstract}

Keywords: public administration, management control, information, public information, communication, goals and tasks.

\section{Introduction}

For a modern human living in the so-called information society ${ }^{1}$, broadly understood information (and its derivatives) is one of the basic commodities. Of course, information may be of different nature - from standard, purely informative data to information with special meaning and legal status. Thanks to information, i.a. obtained or created by public administration as well as information

1 The present term „information society” focuses on the axiological aspect; it has replaced the previously used „information society” in the meaning related more to information technologies. More about information society, i.a.: CWALINA, Wojciech. Generacja Y ponury mit czy obiecująca rzeczywistość. In ZASĘPA, Tadeusz (ed). Internet - fenomen społeczeństwa informacyjnego. Częstochowa: Edycja Świętego Pawła, 2001, pp. $29-42$. 
transferred outside by this administration, various "products” are created which may also be provided electronically.

Using the interest criterion, all the information, especially transferred or loaded on the Internet, may be divided into personal/private information and socially useful (including public) information ${ }^{2}$. The latter group of information - and strictly speaking, only one part thereof - is the subject matter of my paper, where I analyse the essence, meaning and types of information and communication in the context of achieving goals and performing tasks of the public administration.

\section{Information and communication in management control}

Information and communication (i.e. transferring and receiving information) are important for efficient functioning of each organization, including such specific organisation as public finance sector entities. However, in practice, not much attention is paid to communication and information, as it is assumed they are at least on a satisfactory level - this means that the information is correct and is conveyed in a way comprehensible for the recipient. Only after the control, audit or analysis of the functioning of an entity does it turn out that one of the reasons behind these irregularities was or still is the lack of relevant information and incorrect communication. This is why the so called management control ${ }^{3}$ pays attention to this functional area of public entities; this control constitutes ,a total of activities taken in order to ensure the execution of tasks and objectives in a way that is consistent with the law, effective, efficient and timely" (art. 68 para. 1 of the Public Finance $\mathrm{Law}^{4}$ ).

The European Commission and many EU member states describe this type of control as Internal Control or Public Internal Control. In Poland, the notion "management control” was adopted, so as to distinguish it from the internal

2 See: GOLAT, Rafał. Internet - aspekty prawne. Warszawa: Difin, 2003, p. 15.

3 The term „management control” was introduced in the Polish law with the act of 27 August 2009 - the Public Finance law (original text: Journal of Laws 2009, No. 157, item 1240), whereby it replaced the previously functioning term (i.e. in the previous Public Finance Law of 30 June 2005, Journal of Laws 2005, No. 249, item 2104, as amended) „financial control”. However, it was not only a change of name, but also a change of scope - management control, although it primarily refers to financial control, also includes in its scope other aspects of public finance sector entities.

For management control see e.g.: WINIARSKA, Kazimiera (ed). Kontrola zarzadcza $w$ jednostkach sektora finansów publicznych. Warszawa: Oficyna a Wolters Kluwer business, 2012, pp. 1-246; Kontrola zarządcza w sektorze finansów publicznych. Istota, unormowania prawne i otoczenie. Kompendium wiedzy (wersja 1.0). Warsaw: Public Finance Audit Sector Department - Ministry of Finance, 2012, pp. 1-141. [online]. Available at: $<$ http://www.mf.gov.pl/c/document_library/get_file?uuid=ec119301-3422-4b56-af7d318b470fd973\&groupId=764034>

4 The Public Finance Law of 27 August 2009 (consolidated text: Journal of Laws 2016, item 1870); hereinafter: PFL. 
control, rooted in public administration, which has no managerial character. Although internal control should still be treated as part of management control, it still functions in the institutional dimension, and is manifested in positions and organisational units for internal control, authorised within organisational units of public finance sector entities.

Management control, and more precisely: the management control system functioning in the public finance sector entity, is a dynamic system, adjusted (i.a. to its organisational structure and tasks performed) and adapted to changing internal and external conditions. That's why a model template of management control cannot be developed, be it for a given type of public finance sector entities, or for a particular entity „once and for all”.

Grasping the essence of management control is possible after becoming familiar with the Public Finance Law of 27 August 2009 (it defines i.a. the purpose and entities obliged to ensure the functioning of management control in a public finance sector entity) and with the relevant standards ${ }^{5}$ and guidelines ${ }^{6}$. From among the latter group, particular significance is attached to the Standards of management control ${ }^{7}$, which - as indicated therein - include guidelines for creating, evaluating and improving management control systems.

Discussed standards of management control have one group of standards devoted to this area (D. Information and communication), made up of three standards, i.e.: current information as well as internal and external communication. The standards from this group underline the need to provide both people in charge of an entity and employees with access to information essential for them to perform their obligations correctly ${ }^{8}$. They also point out the need for an inter-

5 Announcement No. 23 of the Minister of Finance of 16 December 2009 as regards the standards of the management control for the public finance sector (Official Journal of the MF 2009, No. 15, item 84), hereinafter: Standards of the management control.

6 Szczegółowe wytyczne w zakresie samooceny kontroli zarządczej dla jednostek sektora finansów publicznych (Announcement No. 3 of the Minister of Finance of 16 February 2011, Official Journal of the MF 2011, No. 2, item 11) and Szczegółowe wytyczne dla sektora finansów publicznych w zakresie planowania i zarządzania ryzykiem (Announcement No. 3 of the Minister of Finance of 6 December 2012 r., Official Journal of the MF 2012, item 56).

7 Standards of the management control - as indicated therein - consider the following international standards: „a) „Internal control - integrated framework concept” and "Risk management in a company" - reports elaborated by the Committee of Sponsoring Organizations of the Treadway Commission - COSO, $b$ ) "Guidelines for the internal control standards in the public sector" - adopted in 2004 by the International Organization of Supreme Audit Institutions - INTOSAI, c) "The Revised Internal Control Standard for Effective Management SEC (2007) 1341 appendix 1".

8 Nowadays, various types of ICT networks are used to transmit information and to communicate (within and outside the entity). Internet is used to share external communication and information, whereas for internal communication and information one tends to resort to the -Intranet. -Extranet is usually used in order to share external communication and information, but limited in particular to supervised or controlled units. 
nal and external communication system in an entity, which should be efficient and effective (i.e. correctly functioning and providing information comprehensible for a given group of recipients) and structured in a way that enables the flow of important and essential information. It seems that in the case of internal communication, such a flow must be possible both in a vertical and horizontal axis. Therefore, solutions existing in an entity should enable in particular the direct communication on an entity manager not only with the managers of departments or organizational units, but also with lower level employees. Communication should also be possible between particular employees on the same level within the organizational structure of the entity.

\section{The notion and essence of information}

Information possessed by public administration is of great importance both for the administration itself and for the citizens and other entities which are hierarchically not subordinated to it. Sharing information (informing citizens) is not only an expression of overt and transparent actions of the state/ public authorities/ public administration, but also an instrument for disclosing the intentions and plans. The citizens who know the state policy, its intentions and plans of the public authorities may easier understand the existing and introduced obligations and prohibitions. This is why one of the important sources of information on the intentions of the state/public authorities are acts, policies and plans which include important information, i.a.: objectives and tasks performed in order to achieve these objectives, methods of their execution and controlling the achievement of intended results ${ }^{9}$. Thanks to these and other sources, a citizen may more consciously participate in the life of a given community and undertake actions consistent with the public interest ${ }^{10}$.

Although many legal acts use the notion of „information”, none of them formulates a legal (statutory) definition of the concept. Nevertheless, the Polish legal system knows multiple types of information (e.g. public information, financial, educational, economic, criminal information), which are legal terms defined most of all by exemplary indication of the data that is included under a particular type of information or what data constitutes a set of particular information.

Information shared by public administration is a certain statement (representation) of particular facts, intentions, mandatory legal regulations etc. Spe-

9 See: NOWORÓL, Aleksander. Planowanie rozwoju terytorialnego w skali regionalnej i lokalnej. Kraków: Wydawnictwo Uniwersytetu Jagiellońskiego, 2007, p. 142.

10 See: TARAS, Wojciech. Informowanie obywateli przez administracje. Wrocław: Zakład Narodowy im. Ossolińskich - Wydawnictwo PAN, 1992, p. 8; SZUSTAKIEWICZ, Przemysław. Dostęp do informacji na podstawie ustawy o dostępie do informacji publicznej. In GARDOCKA, Teresa (ed). Obywatelskie prawo do informacji. Warszawa: Oficyna a Wolters Kluwer business, 2008, p. 13. 
cialist literature assigns various functions to these representations, which may be divided into three categories, i.e. ${ }^{11}$ :

1. Communicative function - information is a statement of facts (e.g. a description of a particular status quo), wishes etc.;

2. Appealing function - information is an utterance containing some expectation that the addressee will behave in accordance with the message received (so called optative);

3. Regulatory function - information is an utterance that changes the normative situation.

Distinguishing between these functions shows what types of utterances public administration may use when performing public tasks. In practice, provided information contain various types of interrelated utterances. This is why it is often hard to define what type of statement we have in particular situation ${ }^{12}$.

The existence of various types of utterances is the result of the fact that while operating within the boundaries of mandatory legal provisions (i.e. operating on the basis and within the limits of $\left.l a w^{13}\right)$, public administration is creative and does not limit its actions only to performing its tasks (applying the law) ${ }^{14}$. It seems that nowadays this „creative” area of the activity of public administration should be expanded, because the dynamically changing reality will in its complexity more and more often require that public administration take on ad hoc, immediate tasks, at the same time suited to the current conditions and particular needs. Nevertheless, in order for this to be possible, it seems necessary to offer a new interpretation of the principle of legality ${ }^{15}$, where the area of acceptable activity of public administration and permitted legislative interference with social relations shall be determined by the public interest ${ }^{16}$. What $\mathrm{H}$. Izdebski and M. Kulesza emphasise on this occasion, it is not only the mandatory law, but also political will that decides what is public interest. This is why the debate on what is public interest has been a bone of contention and a factor that differen-

11 KRAUSE, Peter. Rechtsformen des Verwaltungshandelns. Berlin: Duncker \& Humblot, 1974, pp. 60-61 as cited TARAS, Wojciech. Informowanie obywateli przez administracje. Wrocław: Zakład Narodowy im. Ossolińskich - Wydawnictwo PAN, 1992, p. 14.

12 TARAS, Wojciech. Informowanie obywateli przez administrację. Wrocław: Zakład Narodowy im. Ossolińskich - Wydawnictwo PAN, 1992, p. 14.

13 Pursuant to Article 7 of the Constitution of the Republic of Poland of 2 April 1997 (Journal of Laws 1997, No. 78, item 483) each public authority is obliged to follow them and act within the limits of the law (the legality principle).

14 TARAS, Wojciech. Informowanie obywateli przez administrację. Wrocław: Zakład Narodowy im. Ossolińskich - Wydawnictwo PAN, 1992, p. 14.

15 See: MITUŚ, Ambroży. Działania faktyczne administracji publicznej a zasada legalizmu - zarys problematyki. In NICZYPORUK, Janusz (ed). Teoria instytucji prawa administracyjnego. Ksiega pamiątkowa Profesora Jerzego Stefana Langroda. Paryż: Polska Akademia Nauk, 2011, pp. 349-359 and the cited bibliography.

16 IZDEBSKI, Hubert, KULESZA, Michał. Administracja publiczna. Zagadnienia ogólne. Warszawa: Liber, 2004, pp. 96-97. 
tiated between political views, thus allowing to distinguish between doctrines and epochs ${ }^{17}$; it follows from the fact that a change in political will brings about relevant amendments in the law, and consequently, changes in the function of public administration, its objectives and tasks as well as forms and operational methods.

As mentioned before, information provided by public administration should be classified as the so called statements of knowledge. As W. Taras claims, a feature that distinguishes utterances classified as statements of knowledge (i.e. information) from those containing regulations (i.e. norms of conduct) is that the former describe reality and are defined according to the „true-false” criterion, whereas the latter apply the criterion of conformance to the model (i.e. „legal-illegal”). Furthermore, whereas a norm of conduct may be deprived of its power e.g. through a normative or administrative act, information starts its independent functioning from the moment it is shared and may only be rectified, or a new piece of information with a different content can be shared subsequently ${ }^{18}$. In case of doubts whether or not in particular situation you are dealing with information, it is necessary to emphasise that a letter (document) that contains a resolution is definitely not a piece of information, even if it does not have the form stipulated by the law - in this case, it will be an administrative act, not information.

Information shared by public administration should be sufficiently express and clear, so that the information is comprehensible for an average recipient. The comprehensibility of shared information should not only refer to the content, but also to the form of the message. Information shared by public administration should also be socially useful and have relevant content scope, which - if not legally prescribed - should be defined with the consideration of the intention, addressees and objective to be achieved. This need follows from the fact that both laconic and too specialised and extended information may not be understood and absorbed by the addressees. In the latter case, too much information, especially redundant, causes the so called information noise.

Sharing particular information may be an obligation or only a certain right of a public entity. If there is an obligation to keep the citizens informed, legal provisions define: the public administration body or entity obliged to share the information; scope and subject matter of the information; addressees and possibly the time and form of sharing such information ${ }^{19}$.

Providing information - as recognised in the category of legal forms of administrative activity - should be regarded as the so called material and technical activities, i.e. actual activities which in themselves do not produce legal effect,

17 Ibid., p. 97.

18 TARAS, Wojciech. Informowanie obywateli przez administrację. Wrocław: Zakład Narodowy im. Ossolińskich - Wydawnictwo PAN, 1992, pp. 16-17.

19 See: Ibid., pp. 50-51. 
but constitute a preparation for legal actions and for the occurrence of particular results $^{20}$. Therefore, the literature claims that these activities cause legal effects through facts ${ }^{21}$.

\section{Public information}

In public administration, basic type of information is public information which is any piece of information concerning public matters (art. 1 para. 1 of the Law on the Access to Public Information ${ }^{22}$ ). Public information refers to the sphere of facts and data held by public authorities, as well as other entities to the extent they perform public obligations or manage public property ${ }^{23}$. Classifying a particular piece of information as public is done pursuant to the substantial criterion, i.e. the content and character of information ${ }^{24}$. This is why not each piece of information in public administration constitutes public information. By way of an example, even if information transferred between the employees of an entity refers to the performed public tasks, it does not constitute public information due to the lack of the formal value $e^{25}$. Nor do the „applications concerning individual affairs, (...) applications concerning future actions of the authority in individual matters, (...) applications concerning private documents, notes, records and opinions of the officers, even if on the top level, constitute public information if they have not been made official"26.

The right to information is one of the basic rights of a citizen and human being. Therefore, the Constitution of the Republic of Poland ${ }^{27}$ and other legal regulations contain instruments that make it possible to obtain or demand relevant information. Although exercising the right to information is made possible due to the principle of administrative openness, it is the right to information itself that necessitates the creation and maintenance of openness ${ }^{28}$. In a demo-

20 ZIMMERMANN, Jan. Prawo administracyjne. Warszawa: LEX a Wolters Kluwer business, 2014, p. 399.

21 STAHL, Małgorzata. Czynności materialno-techniczne. In STAHL, Małgorzata (ed). Prawo administracyjne. Pojęcia, instytucje, zasady w teorii i orzecznictwie, Warszawa: LEX a Wolters Kluwer business, 2013, p. 486.

22 Law of 6 September 2001 on the access to public information (Journal of Laws 2015, item 2058).

23 See: The Verdict of the Provincial (Voivodship) Administrative Court in Gorzów Wielkopolski of 15 January 2015, II SAB/Go 123/14, LEX no. 1623233.

24 The Verdict of the Provincial Administrative Court in Łódź of 3 March 2015, II SAB/Łd 204/14, LEX no. 1663009.

25 The Verdict of the Supreme Administrative Court in Warsaw of 18 September 2014, I OSK 3073/13, LEX no. 1569520.

26 The Verdict of the Provincial Administrative Court in Rzeszów of 3 June 2014, II SAB/Rz 25/14, LEX no. 1486072.

27 See: art 61 and art. 74 para. 3 of the Constitution of the Republic of Poland of 2 April 1997 (Journal of Laws 1997, No. 78, item 483).

28 WRZESIŃSKI, Krzysztof. Prawo do informacji w procesie cywilnym. In GARDOCKA, Teresa (ed). Obywatelskie prawo do informacji. Warszawa: Oficyna a Wolters Kluwer busi- 
cratic state of law, the right to information - as emphasised by the Supreme Court in one of the verdicts - ,is there to ensure that the public authority is transparent in all its forms and aspects" 29 . In another verdict, the Provincial Administrative Court in Warsaw indicates that the right to information is „a significant element of public life and of the control that the public opinion has over the actions of authorities and bodies. ${ }^{30 "}$

Pursuant to art. 2 para. 1-2 of the Law on the Access to Public Information, the right to public information is granted to anyone, without showing any legal or actual interest. This right includes the right to obtain public information, also the so called processed information ${ }^{31}$; insight into official documents and access to the meetings of collective public authority organs originated in the course of public elections. Therefore, the right to public information includes not only the right to obtain information (being informed), but also sharing the sources of such information ${ }^{32}$. Providing public information is the responsibility of the authority/public entity which holds it; the fact that a particular piece of information has been created within the competence of another organ/public entity is immaterial $^{33}$.

The right to public information does not have absolute character and is subject to restraint. This restraint may be imposed only pursuant to the law and due to the protection of the freedom and rights of other people and business entities and due to the protection of public order, security or important economic interest of the state (art. 61 para. 3 of the Constitution of the Republic of Poland). The Law on the Access to Public Information specifies constitutional norms: in art. 5 para. 1-2 it claims that the right to information is subject to restraint to the extent and pursuant to the rules defined in the provisions related to the protection of confidential information and on the protection of other secrets subject to statutory protection ${ }^{34}$, as well as due to personal privacy or corporate secret.

ness, 2008, p. 201.

29 The Verdict of the Supreme Court of 8 December 2015, II PO 2/15, LEX no. 1996831.

30 The Verdict of the Provincial Administrative Court in Warsaw of 20 November 2012, II SAB/Ld 1527/12, LEX no. 1249113.

31 In the case of processed information, it is possible to obtain it only to the extent it is particularly important for the public interest. Processed information is understood as public information which will be „specially” prepared for the requestor. Therefore, its creation will require intellectual effort and involvement on the part of the entity obliged to provide such information, with the use of additional means and resources, on the basis of the data held by this entity, with regard to the requestor's demand and pursuant to the criteria indicated by the requestor. See: The Verdict of the Provincial Administrative Court in Poznań of 10 December 2014, IV SA/Po 940/14, LEX no. 1575922.

32 The Verdict of the Provincial Administrative Court in Szczecin of 16 July 2014, I SA/Sz 144/14, LEX no. 1490138.

33 OLEJNICZAK-SZAŁOWSKA, Ewa. Zasada jawności administracyjnej. In STAHL, Małgorzata (ed). Prawo administracyjne. Pojęcia, instytucje, zasady w teorii i orzecznictwie, Warszawa: LEX a Wolters Kluwer business, 2013, p. 155.

34 In the Polish legal system, restraints in the access to the public information are regulated 
Restraining access to information does not refer to the information on people holding public functions, information related to holding such functions, including the information on the conditions of assigning and performing such functions, as well as in the case when a natural person or an entrepreneur waive a right they are entitled to (art. 5 para. 2 sent. 2 of the Law on the Access to Public Information).

Sharing public information is done by: announcing public information, including official documents, in the Public Information Bulletin (BIP); sharing in the so called central repository; exposing or putting up in generally accessible places; sharing information on request; introduction to the meeting of collective public authority organs formed in the course of public elections and sharing materials documenting such meetings (art. 7 para. 1 clause 1-4 of the Law on the Access to Public Information).

One of the tools that make it possible to share public information is the abovementioned BIP, used for general sharing of public information in the form of uniform system of websites in an ICT network ${ }^{35}$. It is a useful, although underappreciated tool, which enables a one-way transfer of public information held by a particular public entity. Although by nature it does not ensure the exchange of information with external entities, but only makes it possible to become familiar with information uploaded therein, the data contained in the tool may undoubtedly be used for information exchange through other tools (e.g. e-mail). However, it is possible only if the information contained therein is useful (i.e. updated, complete and provided in a comprehensible form). From such a source as BIP the information may be obtained by the employees of a particular entity as well as the employees of subordinated or controlled entities. It should also be emphasised that BIP is the only legally defined place (official ICT publisher) used for publishing any public information, not only this indicated in art. 8 para. 3 of the Law on the Access to Public Information, defining the minimum scope of shared data. It should be noted that even in the situations when information disclosure is excluded, the scope and legal basis of such exclusion is stated and the organ or person who performed such exclusion is indicated, and in some cases ${ }^{36}$, also the entity for the benefit of which the exclusion of disclosure was made (art. 8 para. 5 of the Law on the Access to Public Information). Public information shared in

first of all by the Law on the Protection of Classified Information of 5 August 2010 (consolidated text: Journal of Laws 2016, item 1167), and a few dozen other normative acts including provisions on „other secrets protected by law” mentioned in art. 5 para. 1 of the Law on the Access to Public Information. Due to this, en entity obliged to provide public information, on the one hand must consider the existing restraints to granting such information, and on the other hand must remember that if it fails to share public information (although it should do so) - it will face criminal liability as specifically defined in art. 23 of the Law on the Access to Public Information.

35 See: art. 8 para. 1 of the Law on the Access to Public Information.

36 See: art. 5 para. 2 of the Law on the Access to Public Information. 
BIP or the central repository ${ }^{37}$ is not subject to the obligation of being shared on request (art. 10 para. 1 of the Law on the Access to Public Information).

The opportunities offered by BIP, when fully used, make it a tool that can serve to create the image of an entity as a subject functioning properly, not having anything to hide and performing its imposed duties in a model manner (which can be relatively easily checked). BIP may provide reliable information on any signs of activity on the part of public administration and reinforce the citizens' awareness (i.e. realising the existence of certain facts) as regards social, economic and legal conditions that impact the functioning of an entity and the actions it takes. Placing a piece of information in BIP constitutes a certain substitute of participating in public life (passive participation) and facilitates social control over the actions of public administration. Furthermore, what is important in the context of management control, information placed in BIP does not require any actions related to it being shared on request, and in turn, it does not involve the employees, who can deal with other activities leading to the achievement of assigned objectives.

Pursuant to art. 10 para. 1 of the Law on the Access to Public Information, public information which has not been shared in BIP or the central repository is shared on request. The provisions of the Law on the Access to Public Information define the rules for sharing information that is not published in BIP, the dates of such sharing, the cost, manner and form of a refusal to share public information and discontinuance of the proceedings related to sharing such information.

Incorrect and unreliable maintenance of BIP, including i.a. untimely upload of information or uploading partial, incomplete information may jeopardise the achievement of assigned objectives by the public entity. The main reason is the fact that among the basic information included in BIP is the data related to the manner of dealing with a particular affair. Therefore, a wrongly presented procedure, incorrect form or list of necessary documents (attachments) will delay and impede the proceedings instead of simplifying and accelerating them - not to mention the adverse impact on the image of the entity/office. First of all, it should be mentioned that from the legal point of view, failure to upload information e.g. on vacancies may trigger an accusation of the lack of disclosure or limiting the competition - in the case of a failure to upload information on the proceedings related to the commissioning of a public task.

To summarise the considerations of public information, one may ask a question whether apart from public information, public administration owns any other types of information. Definitely. At this point, one should mention „pri-

37 Pursuant to art. 9a para. 1 of the Law on the Access to Public Information, central repository is the place for sharing public information that is of particular importance for the development of innovation within the state and the growth of information society. Due to the manner of storage and sharing, this information may be used again in a useful and effective way. 
vate information" obtained e.g. with regard to solving private affairs, or working information useful for completing tasks and shared within a public entity and having no formal character. What is close to this division is the classification of information into external (i.e. information to be shared) and internal (i.e. information not to be shared) such as private and working information. On this occasion, one should note that in this classification, not every piece of public information is external, because not every piece of public information is subject to sharing. Furthermore, in the context of the management control it should be stated that although not every piece of information held by public administration is of public nature, each type of information (which does not mean every single piece of information) contributes to achieving the goals and objectives by the public administration.

\section{The notion and forms of communication}

Communication is, generally speaking, exchange of messages between two entities or parties; it is transmitting and receiving information (messages, data) in a way comprehensible for both parties. Such understanding of communication is strictly linked to the content of information. This is why e.g. even the best legal opinion written in a language that is incomprehensible for the recipient is not an element of correct communication, but only a formal document; in extreme situations, instead of helping to achieve the goals of an entity, it may jeopardise it when wrongly read and incorrectly interpreted by the recipient. The same is valid for communication with external entities, especially with particular community - a wrongly understood piece of information may contribute to the increase of doubts and exacerbating a conflict rather than eliminate doubts and solve conflicts. This is why - especially in the context of public administration correct communication is important, which involves:

- communication (i.e. exchanging messages) with those who need a particular message,

- as much communication (i.e. the scope of message, information) as needed,

- communication in such a form that is the most adequate in a particular case (for a particular matter) and legally acceptable,

- communication at the time when it is needed (i.e. transferring the message at a particular point in time).

Correct communication impacts the effectiveness and efficiency of the actions taken. As regards the management control, it refers to such information and such conveying that is related to achieving certain objectives and goals. In this context, it seems that an instrument of communication may be anything that enables the transfer of messages between entities, including any devices and ICT solutions. However, at the very beginning we are faced with a question of whether such communication may take place with the use of various so called 
social media (e.g. Twitter, Facebook). It seems that in this respect it is crucial what public administration is communicating (i.e. what the conveyed message refers to). Although various forms of communication may be indicated (oral, written, also electronic) with various impact (information addressed to a defined or undefined recipient) and various means of communication, including distant communication means, in many cases public administration is now allowed to use them freely, because legal provisions define both the form of communication and the means of communication that can be used. Pursuant to the provisions of the act on the IT development of the bodies performing public tasks ${ }^{38}$ - public bodies may perform their tasks with the use of an ICT system ${ }^{39}$ or via electronic communication $^{40}$ (art. 13 para. 2$)^{41}$. As an example we could quote providing information to the citizens (inhabitants) via text messages, especially when notifying them on the existing or pending threat.

Restraints as regards the use of forms and means of conveying information refer in particular to public information. Pursuant to art. 7 para. 1 clause 1 of the act of the Access to Public Information, one of the ways to share public information, including official documents, is to announce them in BIP. As mentioned before, public information which has not been shared in BIP or the central repository is shared on request. This means that only public information published in BIP or the central repository shall be treated as shared in the light of this act. That's why public information shared e.g. on the Internet websites of entities obliged to share public information or public information functioning in public domain, but not shared in the abovementioned manner, shall be treated as not shared and must be shared on request. This was confirmed in one of the verdicts of the Supreme Administrative Court of Poland in Warsaw ${ }^{42}$.

We can also look at the situation from another angle, i.e. from the point of view of a person requesting public information to be shared. We can ask: is it

38 The act of 17 February 2005 on the IT development of the bodies performing public tasks (consolidated text: Journal of Laws 2014, item 1114); hereinafter: the act on ITD.

39 The provision of art. 3 clause 3 of the act on ITD explains an ICT system as „a set of cooperating IT devices and software, ensuring the processing, storage as well as sending and receiving data by ICT networks through an IT end device appropriate for a particular network type (...)".

40 Pursuant to art. 3 clause 4 of the act on ITD in connection with art. 2 clause 5 of the act of 18 July 2002 on electronic services (consolidated text: Journal of laws 2016, item 1033), electronic means of communication are defined as „such technical solutions, including ICT devices and cooperating programme tools which make it possible to communicate individually at a distance with the use of data transmission between ICT systems, in particular electronic mail".

41 More about it, see: art. 13-20c of the act on ITD. These provisions define i.a. basic requirements that ICT systems should conform to (e.g. interoperability); these requirements are defined specifically in implementing acts (lower-order acts).

42 The Verdict of the Supreme Administrative Court in Warsaw of 23 September 2014, I OSK 34/14, LEX no. 1569532. 
possible to file an effective request for public information to be shared via social media? Of course, assuming that the entity obliged to share this information has an account/website in such media and setting aside numerous legal doubts related to the use of such media by public entities. However, the answer to the above question was basically provided by the Provincial Administrative Court in Warsaw in the decision of 15 March 2013, in which it rightly stated that in a democratic state of law, in the light of the legality principle, the activity of public authorities (competences, tasks and operational mode) are defined by mandatory legal provisions. This is why the Provincial Administrative Court in Warsaw claims that having a website in social media - in this case it was the website of local authorities - usually only serves „promotional purposes, presents the achievements of the local authorities, defined the intentions and points to social initiatives (...). In the mandatory legal order, this type of website is not an acceptable way of communicating the so called official business, and it is not meant for filing applications and requests" ${ }^{33}$.

One of the solutions which guarantees the citizens and entrepreneurs communications with public administration entity and ensures communication between public administration entities is the electronic platform of public administration services (ePUAP) ${ }^{44}$. It is an ICT system where public entities share their services through a single access point in the Internet ${ }^{45}$. In ePUAP, through the so called ePUAP trusted profile (which is a set of information identifying and describing the account user in ePUAP, whose data has been reliably confirmed by the authorities) it is possible to manage many official affairs. That's why ePUAP is an exponent of e-administration, i.e. administration which uses ICT solutions in performing public services.

\section{Information and communication in management control standards}

Standard of the management control „D 16. Current information” requires that managing staff and employees be guaranteed access to proper and useful, as well as updated and reliable information necessary for the completion of tasks. This information should be transferred in a correct and comprehensible form and in a proper moment. The interest of the management control in this area of public administration is supposed to reinforce and facilitate the execution of tasks and objectives imposed on public finance sector entities. It follows from the fact that information (data) transferred within an entity, regardless of the character (i.e. from purely informative data to the data with special significance and status, e.g. public information), always serve the execution of tasks and objectives.

43 The decision of the Provincial Administrative Court in Warsaw of 15.03.2012, (II SAB/Wa 513/12), LEX no. 1375081.

$44<$ https://epuap.gov.pl/wps/portal>

45 Art. 3 clause 13 of the act on ITD. 
Since the very information transfer is not sufficient to ensure successful execution of tasks and objectives, it is necessary to communicate with subjects inside and outside the entity. Proper internal communication in public administration requires effective mechanisms for sharing important information both within the organisational structure of an entity (level I of the management control), and within the department of government administration and local government unit (level II of the management control) ${ }^{46}$. To this end, there are relevant procedures and various solutions related to e-office, which ensure i.a. optimum document flow and timely handling of affairs. However, just like the lack of procedures may be a problem - excess of the same may be a trouble, too (overregulation).

In order to prevent falsifications, information should be transferred directly to the person interested in it. Additionally, atmosphere at work should encourage people to ask questions related to the assigned tasks and to provide honest answers; communication style has considerable role in this respect - the same information may be shared in multiple ways, and consequently, it may also be received in a number of ways. However, the key element in communication is a competent and communicative employee. This is why the mandatory provisions related to the so called official pragmatics ${ }^{47}$ as well as internal recruitment procedures are supposed to ensure the selection of the best candidate for a particular job.

With reference to external communication, Standards of the management control require an effective system for the „exchange of important information with external subjects that impact the achievement of objectives and execution of tasks". This is reasonable, because correct communication undoubtedly contributes to efficient and effective achievement of an assigned objective within an assumed deadline. This is why public administration, especially regional authorities, and most of all municipal authorities, should keep the public informed at least of the most important public affairs.

A useful communication tool, especially in the municipal government, may be own websites, where a public entity itself decides on the type and scope of published information. On one's own website an entity may publish information related to e.g. important events from the life of the community (photos, films, etc.), which do not constitute public information. Having one's own website seems a relatively cheap tool for keeping the inhabitants informed and promoting the municipality, because the information uploaded there will surely impact the perception of the municipality, also with regard to its tourist or investment value and attractiveness.

46 See: Standards of the management control.

47 Here we should mention the act of 21 November 2008 on local government employees (consolidated text: Journal of Laws 2016, item 902); act of 21 November 2008 on civil service (consolidated text: Journal of Laws 2016, item 1345); and the act of 16 September 1982 on public officials (consolidated text: Journal of Laws 2013, item 269). 
The role of an intermediary in transferring information could be assigned to the media, but they do not usually inform the public on correct (efficient, effective etc.) actions of public administration, but on scandals, corruption and all other types of irregularities. If they do take on the role of an intermediary, then such a message is often a result of the actions taken by public administration, which shares information with the media during various press conferences, interviews, briefings or e.g. in a local news bulletin.

\section{Conclusion}

As W. Taras emphasises, information is the statement of knowledge issued by a public administration body or another administrative entity, made in the form of material and technical activity and related to the particular actual or legal status, or consequences following from $\mathrm{it}^{48}$.

One of the categories of information owned by public administration is public information, characterised by the formal status and the value related to the domain of public facts and data. Such information is meant to be shared, whereby it enables the citizens to control the activity of public administration and increases the public officials' feeling of responsibility for the actions they perform. In this respect, information is the means and guarantee of democratisation of public life ${ }^{49}$.

In the context of management control, having relevant information and sharing it with entities that impact the execution of tasks and objectives is an essential factor facilitating the achievement of assumed effects. It seems that many people may confirm that at least on one occasion they failed to achieve particular goal (and a noble goal it was indeed), only because of a lack of reliable information and proper communication. Information and communication make it possible to eliminate or reduce the apprehensions and to understand the decisions made and actions performed. If the citizens are additionally guaranteed the opportunity to influence the decisions that are made, if only by having their suggestions/proposals considered, this will probably reinforce the authority of a public entity to take actions and will be beneficial for all the stakeholders. This is why it is worth introducing communication rules applicable in the situations when mandatory legal provisions do not specify the requirements, especially in territorial organs, which are nearest to the citizen.

Finally, it should be mentioned that a public entity having relevant information must also manage it in a proper way. It should not only implement a correct information policy, but also - although this wasn't included in the analysis introduce a proper information security policy defined in legal provisions and

48 TARAS, Wojciech. Informowanie obywateli przez administrację. Wrocław: Zakład Narodowy im. Ossolińskich - Wydawnictwo PAN, 1992, p. 21.

49 Ibid., p. 29. 
ICLR, 2016, Vol. 16, No. 2.

e.g. in a document containing the rules for information management and sharing as well as for protecting the information against destruction, unauthorized modification or unauthorized use $\mathrm{s}^{50}$.

50 SŁAWIŃSKA-TOMTAŁA, Ewa. Kontrola zarzadcza $w$ sektorze publicznym. Praktyczne wskazówki wdrożenia systemu, C.H.Beck, Warszawa: Wydawnictwo C. H. Beck, 2010, p. 74. The obligations of a public entity related to the implementation and use, monitoring and review as well as maintenance and development of the information security management system in electronic form are defined in particular in $\$ 20$ of the Regulation of the Council of Ministers of 12 April 2012 as regards the National Interoperability Frameworks, minimum requirements for public registers and electronic information exchange as well as minimum requirements for ICT systems (consolidated text: Journal of Laws 2016, item 113). 